\title{
Correction to: Rural-urban differences in quality of life and associated factors among community-dwelling older persons in Oyo state, South-Western Nigeria
}

\author{
Eniola O. Cadmus ${ }^{1,2} \cdot$ Lawrence A. Adebusoye $^{2} \cdot$ Eme T. Owoaje $^{1}$
}

Published online: 30 October 2021

(c) The Author(s) 2021

\section{Correction to: Quality \& Quantity https://doi.org/10.1007/s11135-021-01178-8}

The original article was published with incorrect Funding statement. The complete Funding statement is given in this correction.

Funding This research was supported by the Consortium for Advanced Research Training in Africa (CARTA). CARTA is jointly led by the African Population and Health Research Center and the University of the Witwatersrand and funded by the Carnegie Corporation of New York (Grant No-G-19-57145), Sida (Grant No: 54100113), Uppsala Monitoring Centre and the DELTAS Africa Initiative (Grant No: 107768/Z/15/Z). The DELTAS Africa Initiative is an independent funding scheme of the African Academy of Sciences (AAS)'s Alliance for Accelerating Excellence in Science in Africa (AESA) and supported by the New Partnership for Africa's Development Planning and Coordinating Agency (NEPAD Agency) with funding from the Wellcome Trust (UK) and the UK government. The statements made and views expressed are solely the responsibility of the Fellow.

Open Access This article is licensed under a Creative Commons Attribution 4.0 International License, which permits use, sharing, adaptation, distribution and reproduction in any medium or format, as long as you give appropriate credit to the original author(s) and the source, provide a link to the Creative Commons licence, and indicate if changes were made. The images or other third party material in this article are included in the article's Creative Commons licence, unless indicated otherwise in a credit line to the material. If material is not included in the article's Creative Commons licence and your intended use is not

The original article can be found online at https://doi.org/10.1007/s11135-021-01178-8.

Eniola O. Cadmus

eniyolacadmus@gmail.com

Lawrence A. Adebusoye

larrymacsoye27@gmail.com

Eme T. Owoaje

emetheodora@gmail.com

1 Department of Community Medicine, College of Medicine, University of Ibadan, Ibadan, Oyo, Nigeria

2 Chief Tony Anenih Geriatric Centre, University College Hospital, Ibadan, Nigeria 
permitted by statutory regulation or exceeds the permitted use, you will need to obtain permission directly from the copyright holder. To view a copy of this licence, visit http://creativecommons.org/licenses/by/4.0/.

Publisher's Note Springer Nature remains neutral with regard to jurisdictional claims in published maps and institutional affiliations. 